\title{
Host-Specific Relationship Between Virus Titer and Whitefly Transmission of Cucurbit yellow stunting disorder virus
}

William M. Wintermantel, United States Department of Agriculture-Agricultural Research Service (USDA-ARS), Salinas, CA 93905; Robert L. Gilbertson, Department of Plant Pathology, University of California, Davis 95616; James D. McCreight, USDA-ARS, Salinas; and Eric T. Natwick, University of California Cooperative Extension Imperial County, Holtville 92250

\begin{abstract}
Wintermantel, W. M., Gilbertson, R. L., McCreight, J. D., and Natwick, E. T. 2016. Host-specific relationship between virus titer and whitefly transmission of Cucurbit yellow stunting disorder virus. Plant Dis. 100:92-98.

Cucurbit yellow stunting disorder virus (CYSDV; genus Crinivirus, family Closteroviridae) was identified in the melon (Cucumis melo) production regions of the desert southwestern United States in fall 2006. It is now well established in the region, where it is transmitted efficiently by the sweet potato whitefly, Bemisia tabaci biotype B (MEAM1). In order to evaluate the spread and establishment of the virus, nearly all spring and fall cucurbit fields planted in the Imperial Valley of California from 2007 to 2009 were surveyed and representative plants were tested for CYSDV infection. Incidence of CYSDV in spring melon fields was initially low and limited to a small number of fields in 2007 but increased to $63 \%$ of fields by spring 2009 . Virus incidence in fall melon fields was $100 \%$ in each year. These results suggested that the virus had become established in native vegetation, weeds, and other crop species, and represented an increasing threat to melon production in the southwestern United States. Therefore, a select set of weed and crop species which grow or are cultivated in the Imperial Valley were evaluated as CYSDV

reservoir hosts. For each species, we determined the capacity of CYSDV to accumulate, the relationship between virus titer in these source plants and transmission by whiteflies, as well as subsequent accumulation in inoculated cucurbit plants. Among these hosts, there was considerable variation in virus accumulation and transmission rates. Cucurbit hosts had the highest CYSDV titers, were efficient sources for virus acquisition, and showed a positive correlation between titer in source plants and transmission. Noncucurbit hosts had significantly lower CYSDV titers and varied in their capacity to serve as sources for transmission. CYSDV titers in some noncucurbit source plants, specifically common bean (Phaseolus vulgaris) and shepherd's purse (Capsella bursa-pastoris), were not positively correlated with transmission, demonstrating that additional environmental, physical, or biochemical factors were involved. These results demonstrate that multiple factors influence the efficiency with which a host plant species will be a reservoir for vector transmission of virus to crops.
\end{abstract}

Cucurbit yellow stunting disorder virus (CYSDV) is a whiteflytransmitted crinivirus (genus Crinivirus, family Closteroviridae) that was originally discovered in the United Arab Emirates in 1982 (Hassan and Duffus 1991). The virus has since spread throughout the Middle East and Mediterranean Basin, including Lebanon, Israel, countries of North Africa and Southern Europe, as well as the Canary Islands (Abou-Jawdah et al. 2000, Célix et al. 1996, Desbiez et al. 2000, Louro et al. 2000, Wisler et al. 1998). CYSDV was first detected in the New World in Texas in 1999 (Kao et al. 2000). In August and September 2006, CYSDV was detected in the melon (Cucumis melo) production regions of the desert southwestern United States, including the Imperial Valley of California and adjacent Yuma, AZ region (Kuo et al. 2007). The virus was also detected in central Arizona and Sonora, Mexico (Brown et al. 2007). By the end of the fall 2006 growing season, most melon plants in most fields in the Imperial-Yuma region showed symptoms of CYSDV infection, and the presence of the virus in representative symptomatic plants from these fields was confirmed by reverse-transcription polymerase chain reaction (RT-PCR) analysis (Kuo et al. 2007). In 2007, CYSDV was detected in Florida (Polston et al. 2008), demonstrating the rapid expansion of its geographical range.

In the early stages of CYSDV infection, cucurbit leaves show yellow spotting and mottle symptoms. These initial symptoms are followed by more extensive interveinal chlorosis, in which leaf tissue

Corresponding author: W. M. Wintermantel;

E-mail: bill.wintermantel@ars.usda.gov

Accepted for publication 29 June 2015.

http://dx.doi.org/10.1094/PDIS-11-14-1119-RE

(c) 2016 The American Phytopathological Society between veins turns yellow, with the veins remaining green. Symptoms progress from the older leaves, near the center of the plant, down vines, with the younger leaves remaining green until symptoms in older leaves become prominent (Célix et al. 1996; Tzanetakis et al. 2013; Wisler et al. 1998). Foliar symptoms of CYSDV infection are easily confused with those of abiotic disorders, such as nutrient deficiency. Fruit of infected plants may show no symptoms but sugar levels ( ${ }^{\circ}$ Brix) are typically reduced (Abou-Jawdah et al. 2000; López-Sesé and Gómez-Guillamón 2000), resulting in poor marketability. In cases of severe disease outbreaks, entire melon fields may exhibit a striking yellow coloration, which is typical of crinivirus infection (Tzanetakis et al. 2013).

CYSDV is transmitted exclusively by Bemisia tabaci. As with other members of the genus Crinivirus, transmission occurs in a semipersistent manner, and the virus does not replicate within the insect vector (Wintermantel 2010; Wintermantel [in press]; Wisler et al. 1998). It is neither seedborne nor mechanically transmitted (Tzanetakis et al. 2013). Whiteflies acquire the virus by feeding on infected plants and remain viruliferous for up to 9 days (Célix et al. 1996; Wisler et al. 1998). The B. tabaci biotypes A (NewWorld1), B (MEAM1), and Q (MED) transmit CYSDV. However, the invasive biotypes $B$ and $Q$ transmit the virus more efficiently than the North American A biotype, which is no longer found in the field (Berdiales et al. 1999; Wisler et al. 1998). In the United States, CYSDV is transmitted by the B biotype, which is the predominant B. tabaci biotype in the southwestern United States (Chu et al. 2007). The Q biotype has been identified in several states but mainly in greenhouses, and it has not become established in the field (Dickey et al. 2013; McKenzie et al. 2009, 2012). Thus, because nearly all U. $S$. melon crops are produced in the field, the vector of greatest importance to U.S. production is $B$. tabaci biotype B. CYSDV is spread over long distances by the movement of infected plants or by viruliferous whiteflies (B. tabaci). Because it can take up to 4 weeks for disease symptoms to develop in cucurbit plants after inoculation with 
CYSDV, the virus can be transported in transplants in which symptoms have yet to develop (Tzanetakis et al. 2013).

In the Imperial Valley of California, B. tabaci populations increase gradually during the spring melon season and reach high levels during the fall season (Chu et al. 2007). The high populations of $B$. tabaci during the fall melon season in the desert southwestern United States facilitate rapid and efficient transmission of whitefly-transmitted viruses among crop and weed hosts (Wisler and Duffus 2001). Prior to its discovery in California, CYSDV was believed to have a narrow host range, primarily restricted to cucurbits (Célix et al. 1996; Wisler et al. 1998). However, it has been established that CYSDV has a much broader host range than previously believed (Wintermantel et al. 2009). Weed and noncucurbit crop hosts of CYSDV identified in the southwestern United States include common bean, (Phaseolus vulgaris), lettuce (Lactuca sativa), alkali mallow (Sida hederacea), ground cherry (Physalis wrightii), and the wild cucurbit, buffalo gourd (Cucurbita foetidissima). Many hosts do not show obvious symptoms but some were found to serve as CYSDV sources for transmission to cucurbits (Wintermantel et al. 2009).

Melon production in the southwestern United States accounts for $80 \%$ of the U.S. cantaloupe crop and $96 \%$ of the U.S. honeydew melon crop. Thus, the importance of this region for U.S. melon production warranted aggressive efforts to develop effective management strategies to mitigate losses due to CYSDV. To this end, it was necessary to better understand the ecology and epidemiology of CYSDV in the southwestern United States. Therefore, studies were conducted to (i) evaluate the emergence and spread of CYSDV during spring and fall melon seasons and (ii) determine the relationship between CYSDV titer in various host plants and their capacity to serve as reservoirs for transmission of the virus to cucurbits.

\section{Materials and Methods}

Field surveys and plant sampling. Following the emergence of CYSDV in fall 2006 and rapid spread of the virus throughout the Imperial Valley (Kuo et al. 2007), systematic surveys were implemented to determine time of emergence and incidence of CYSDV in melon and watermelon (Citrullus lanatus) fields in the Imperial Valley. These surveys were conducted in the spring and fall melon seasons from 2007 through 2009. The locations of surveyed fields were identified with assistance from the Imperial County Agricultural Commissioner and were based upon permit requests for pesticide applications. Each field was visually evaluated for CYSDV-like symptoms by a team of two people walking a line between the diagonal corners of the field. Leaves with CYSDV-like symptoms (e.g., yellow spots, mottling, or interveinal yellowing) were collected. Samples were stored on ice and shipped to the United States Department of Agriculture-Agricultural Research Service (USDA-ARS) in Salinas and the University of California-Davis and tested for CYSDV by RT-PCR.

The symptom severity and virus titer in three CYSDV-susceptible commercial melon cultivars commonly grown in the region ('Top Mark', 'Laredo', and 'Impac') were determined in 2010, 2011, and 2012 to obtain baseline information for subsequent whitefly transmission experiments. Samples of these cultivars were collected from CYSDV resistance breeding field trials at the University of California Desert Research and Extension Center, Holtville. Melon plots were established with standard commercial practices as described by McCreight and Wintermantel (2012). Plants within plots were individually evaluated approximately 10 weeks postplanting for CYSDV symptoms using a 1-to-10 rating scale, with 1 representing less than $10 \%$ of foliage showing symptoms and 10 representing $100 \%$ of the foliage exhibiting symptoms. The youngest leaf on a vine showing symptoms was collected and assayed by enzymelinked immunosorbent assay (ELISA) using antisera produced against Escherichia coli-expressed CYSDV capsid protein (Cotillon et al. 2005) (O. Batuman and R. L. Gilbertson, unpublished). The CYSDV data were subjected to analysis of variance (ANOVA) and protected means separations (Student's $t$ test) using JMP 11.1.1 (SAS Institute, Cary, NC).
CYSDV transmission studies. To determine the efficiency of CYSDV transmission to and from weed and crop hosts, and to evaluate the potential of these hosts as virus reservoirs for transmission of CYSDV to cucurbit crops, plants of each host were infected with CYSDV and used as sources for B. tabaci biotype B transmission studies. Leaves of CYSDV-infected cantaloupe (Cucumis melo) or zucchini (Cucurbita pepo) plants were detached and put in a flask containing water, covered with Parafilm (a slit was made in the Parafilm and the leaf or leaves inserted into the slit), then placed in a transmission cage. Large numbers of B. tabaci biotype B that had been reared on broccoli (Brassica oleracea), a nonhost of CYSDV, were then released into the cage and provided an acquisition access period (AAP) of $48 \mathrm{~h}$. Following the AAP, whiteflies were individually collected with a vacuum and placed into leaf clip cages. Cages containing 40 to 100 whiteflies each (exact number varied depending on the type of experiment) were clipped onto the underside of leaves of young plants of each test host plant type for an inoculation access period (IAP) of $48 \mathrm{~h}$. Host plants were usually no more than 1 month old (large seedling stage) at the time of inoculation, although the exact age and developmental stage varied depending on the host plant species. Because seed of alkali mallow ( $S$. hederacea), a common and potentially important noncucurbit reservoir host, was not available, cuttings were collected from the field in Imperial Valley. The cuttings were confirmed to be free of CYSDV by RT-PCR, rooted in the laboratory, and used for transmission experiments when plants were approximately $8 \mathrm{~cm}$ tall. Plants were sprayed with Resmethrin (Whitmire Inc., St. Louis) to kill whiteflies following the 48-h IAP, and placed in net cages (54 mesh) in growth chambers (Conviron, Winnipeg, Manitoba, Canada) for 4 weeks. Growth chambers were maintained at $27^{\circ} \mathrm{C}$ with 14 -h days and light at approximately $220 \mu \mathrm{E} \mathrm{m}^{-1} \mathrm{~s}^{-2}$. One week postinoculation, inoculated leaves were removed from plants to prevent whitefly eggs and nymphs from maturing to adults. Four weeks after inoculation, total RNA was extracted from newly emerged (noninoculated) leaves of each plant and assayed for CYSDV infection by RT-PCR.

To evaluate the relationship between virus titer and Bemisia tabaci transmission of CYSDV to melon from potential reservoir hosts, and transmission efficiency of CYSDV to and from zucchini, subsets of CYSDV-infected host plants were selected and used as sources for virus transmission. RT-quantitative (q)PCR) was performed as described below to determine virus titers in source plants prior to transmission. The CYSDV-infected source plants to be used in transmission experiments were selected to represent the range of virus titers as determined for each host species by RT-qPCR. These selected source plants were used for transmission experiments within $48 \mathrm{~h}$ of virus titer determination. Fully expanded leaves of source plants were used for virus acquisition (48 h AAP) as described above. If plants exhibited CYSDV symptoms, symptomatic leaves were used for virus acquisition; however, many hosts did not exhibit virus symptoms. Following the AAP, 35 or 50 whiteflies were vacuum collected and placed into leaf clip cages, and two clip cages were attached to the abaxial surface of melon or zucchini leaves (depending on the experiment) for a 48-h IAP. Approximately 4 weeks after transmission symptoms of CYSDV appeared on leaves of inoculated melon or zucchini plants, total RNA was extracted from newly emerged leaves and CYSDV infection was determined by RTPCR. Viral titer in melon was determined by RT-qPCR as described below.

RT-PCR. Total RNA was extracted from leaf tissue using a modification of the method of Dellaporta et al. (1983) adapted for RNA, or with the Qiagen RNeasy Plant Mini Kit (Qiagen, Valencia, CA), and RNA was stored at -20 or $-80^{\circ} \mathrm{C}$. The positive control consisted of total RNA extracted from CYSDV-infected melon or zucchini leaf tissue. The negative control was total RNA extracted from uninfected plants and, in some cases, weed and crop test-host species. RT-PCR with total RNA extracts from test host species, as well as positive and negative controls and a reagent-only control, was conducted as described previously with a CYSDV capsid protein $(\mathrm{CP})$ gene primer pair that directs the amplification of a 394-bp DNA fragment (Wintermantel et al. 2009). 
RT-qPCR. Total nucleic acids were extracted from $0.1 \mathrm{~g}$ of leaf tissue with the modified method of Dellaporta et al. (1983) and analyzed immediately. The quantity and quality of the nucleic acid template was determined by spectrophotometry (NanoDrop 2000; Thermo Scientific), and the absence of PCR inhibitors was confirmed using the $\mathrm{Cq}$ dilution series method (Bustin et al. 2009). The RT-qPCR primers, TaqMan probe, and protocols used in this study were designed and validated by Papayiannis et al. (2010). The RT-qPCR assay was performed with a Superscript III Platinum One-Step qRT-PCR kit (Invitrogen, Carlsbad, CA) in a $25-\mu l$ final volume, which included $0.3 \mu \mathrm{M}$ each primer, $0.1 \mu \mathrm{M}$ TaqMan probe, $0.5 \mu l$ of Rnase Inhibitor (Promega Corp., Madison, WI), and $0.5 \mu \mathrm{l}$ of RNA template (samples were adjusted to the same starting concentration). The standard amplification profile was $50^{\circ} \mathrm{C}$ for $30 \mathrm{~min}$ to synthesize cDNA, followed by $94^{\circ} \mathrm{C}$ for $3 \mathrm{~min}$ and 40 cycles of $94^{\circ} \mathrm{C}$ for $10 \mathrm{~s}$ and $60^{\circ} \mathrm{C}$ for $30 \mathrm{~s}$ (Papayiannis et al. 2010). The amplification products were quantified using the absolute method, with a standard curve prepared by cloning a 491-bp fragment of the CYSDV RNA-dependent RNA polymerase (RdRp) gene into the pGEM-T Easy vector (Promega Corp.). The plasmid was linearized and a $10^{6}$-fold dilution series was prepared. To determine virus titer, the copy number of the standard target was calculated based on spectrophotometric determination of the initial plasmid DNA concentration. Mean CYSDV copy numbers for each test-host species were analyzed by ANOVA (JMP 7.0; SAS Institute).

\section{Results}

Field surveys. Surveys of spring melon fields were conducted from late May to mid-June in 2007 to 2009. The first spring survey followed the initial CYSDV outbreak (fall 2006) and was conducted on 18 June 2007, toward the end of the growing season. Only one field with a small number of symptomatic plants was identified, and CYSDV infection was confirmed in those plants by RT-PCR. Two surveys were conducted in spring 2008. The first survey was on 2 May to determine whether fields with CYSDV-infected plants could be identified relatively early in the season, whereas the second was conducted 11 and 12 June to coincide with the sampling time of the previous year. Twelve fields were surveyed on 2 May, and plants with CYSDV symptoms were observed in one field. CYSDV infection in representative symptomatic plants from this field was confirmed by RT-PCR. In the 11 and 12 June survey, 11 of 28 fields surveyed (39\%) had plants with CYSDV symptoms. Of these 11 fields, 10 were melon (cantaloupe and honeydew) and 1 was a watermelon field. The incidence of CYSDV symptoms was relatively low in most fields ( $\leq 5 \%$ ), although some fields had incidence as high as $10 \%$. Infection of representative symptomatic plants was confirmed by RT-PCR. The spring 2009 survey was conducted on 29 May. Although whitefly populations were not very high, the survey revealed a much higher incidence of CYSDV than in spring 2008 and 2009. In all, 25 of 40 fields surveyed (63\%) in spring 2009 had typical symptoms, and CYSDV infection of representative plants was confirmed by RT-PCR. Furthermore, disease development was more advanced in 2009, with many plants showing extensive yellowing symptoms at or near harvest, compared with the mild mottling or interveinal chlorosis observed in plants at the same stage of development in 2007 and 2008. These results indicated that the incidence of CYSDV in spring melon crops in the Imperial Valley increased each year of the survey.

During the spring 2008 survey, plants in a number of fields also showed mosaic and dark-green blistering symptoms, which were determined to be associated with potyvirus infection based on RT-PCR analysis with degenerate potyvirus primers (data not shown). Sequence analysis of selected PCR-amplified DNA fragments revealed that the potyviruses were Watermelon mosaic virus and a divergent strain of Zucchini yellow mosaic virus. A number of plants were also coinfected with CYSDV and the begomovirus Cucurbit leaf crumple virus ( $\mathrm{CuLCrV})$, based on symptoms (leaf crumpling and yellowing) and confirmation of coinfection in a limited number of plants by RTPCR and PCR, respectively (Kuo et al. 2007). However, the incidence of $\mathrm{CuLCrV}$ infection was far less (estimated at $\leq 1 \%$ ) than that of CYSDV. In 2007 and 2009, symptoms of potyvirus and CuLCrV infection were rarely observed.

In contrast to the spring melon seasons, the incidence of CYSDV in fall crops was very high each year (approximately 100\%) and symptoms were severe, with plants showing a generalized yellowing. Beginning in fall 2006, when CYSDV was first identified in the Imperial Valley (Kuo et al. 2007), through the end of our survey period in 2009, nearly every plant in all melon fields exhibited strong CYSDV symptoms by the end of each fall season. These high rates of infection were facilitated by the high whitefly populations in the Imperial Valley during the fall melon season, which resulted in early infections and rapid spread of the virus. Following the initial outbreak in 2006, the number of fall-planted melon fields declined dramatically, such that only three melon fields were available for surveys in 2008 and 2009.

To estimate CYSDV titer in susceptible commercial melon varieties, leaves of field-grown plants of two varieties known to be severely affected by CYSDV were collected from research plots and assessed for symptom severity and virus titer over a 3-year period. Leaves were collected in the fall when plants were uniformly infected, and sampling was performed at approximately 10 weeks postplanting. There was no difference in plant condition or symptom severity between these cultivars. Top Mark was used in the 2010 trial and had a mean plant condition score of $4.2 \pm 0.1$ and a mean symptom severity score of $5.5 \pm 0.4(n=10)$. Laredo was used in the 2011 trial and had a mean plant condition score of $4.5 \pm 0.3$ and a mean symptom severity score of $4.5 \pm 0.4(n=10)$. The two cultivars differed significantly $(P=0.05)$ in virus titer, with a mean ELISA value of $0.387 \pm 0.24$ for Top Mark and $0.151 \pm 0.43$ for Laredo. Although these results represented different years, the similar plant condition and severity scores for the cultivars suggested that the conditions for disease development were equivalent. In a limited follow-up study in 2012, three cultivars (Top Mark, Laredo, and Impac) were compared. These three CYSDV-susceptible cultivars had similar plant condition and symptom severity ratings; however, virus titer differed among cultivars, with Top Mark accumulating the highest levels of CYSDV (data not shown).

Whitefly transmission of CYSDV to reservoir hosts. Initial studies compared CYSDV infection rates in six noncucurbit and two cucurbit CYSDV hosts following whitefly transmission from the susceptible source plant, zucchini (C. pepo) (Wintermantel et al. 2009). The highest rates of infection were observed for London rocket $(100 \%)$ and buffalo gourd (84\%), and these were comparable with that of the zucchini control (95\%) (Table 1). Infection rates in shepherd's purse, lettuce, common bean, and alkali mallow ranged from 58 to $80 \%$, whereas transmission to alfalfa was not detected (Table 1). Symptom development was observed in CYSDVinfected zucchini, lettuce, common bean, and buffalo gourd plants, with mild symptoms on alkali mallow. No symptoms were observed in London rocket plants.

Whitefly transmission of CYSDV from potential reservoir hosts. Transmission of CYSDV from infected London rocket and buffalo gourd to zucchini resulted in high rates of infection: 89 and 100\%, respectively. Lettuce, alkali mallow, and common bean were less efficient sources for acquisition of CYSDV, based on lower rates of transmission to zucchini (23 to $33 \%$; Table 1). Shepherd's purse was a particularly poor acquisition host, because only a single zucchini plant became infected in four independent transmission experiments (Table 1).

Alfalfa is the most prevalent crop grown in the Imperial Valley and is a potential perennial CYSDV reservoir because the virus was found infecting alfalfa collected from Imperial Valley fields (Wintermantel et al. 2009). However, previous whitefly transmission tests failed to produce infected alfalfa plants (Wintermantel et al. 2009), and similar results were obtained in the present study (Table 1). In the present study, a single experiment to transmit CYSDV from field-infected alfalfa to zucchini was performed due to the difficulty in identifying and moving CYSDV-infected alfalfa from the field to the laboratory. Nevertheless, in this experiment, four of six zucchini plants became infected following transmission from CYSDVinfected alfalfa (Table 1). Together, these results reveal a need for 
additional studies to clarify the importance of alfalfa as a CYSDV reservoir and its role in disease epidemiology.

Correlation between CYSDV titer and association with transmission efficacy. Plants used as sources for transmission experiments were inoculated with CYSDV as seedlings and maintained for 4 weeks. As expected from previous studies, some hosts exhibited symptoms of CYSDV infection (melon, buffalo gourd, common bean, and, to a lesser extent, lettuce and alkali mallow), whereas others did not (shepherd's purse and London rocket). Top Mark cantaloupe had the highest virus titer, with mean log copy numbers as high as 6.0 (Fig. 1). Buffalo gourd, the cucurbit weed species, had the next highest titer (4.2). Lower values were obtained for lettuce (3.2) and common bean (2.7), and these were higher than those of the other weeds tested, including shepherd's purse (2.5), London rocket (2.2), and alkali mallow (1.7) (Fig. 1).

A subset of these plants was subsequently used to evaluate transmission from CYSDV-infected weed and crop plants to melon plants and to assess whether there is a correlation between viral titer and transmission efficiency, as has been found with other criniviruses. The CYSDV hosts used for these transmission experiments included buffalo gourd, London rocket, shepherd's purse, and common bean. These hosts were selected because they represented the range of virus titers detected by RT-qPCR (Fig. 1).

Among the potential reservoir host plants examined, buffalo gourd, the cucurbit weed, was the most efficient source of CYSDV for transmission to melon. Six CYSDV-infected buffalo gourd plants were used as source plants in independent experiments, and mean log copy numbers in these plants ranged from $3 \times 10^{3}$ to $9 \times 10^{6}$ copies (Fig. 2A). Regardless of virus titer, all melon plants inoculated with whiteflies that acquired virus from buffalo gourd plants became infected (4 melon test plants inoculated per buffalo gourd source plant, for a total of 24 infected/24 inoculated in six experiments). CYSDV accumulation in the inoculated melon plants varied, and was positively correlated with virus titer in the source plant. For the four buffalo gourd plants with the highest virus titers, the titers in the infected melon test plants ranged from $1 \times 10^{4}$ to $9 \times 10^{7}$ copies whereas, for the buffalo gourd plants with the lowest virus titers, a lower accumulation of CYSDV was detected in infected melon $\left(<10\right.$ to $1 \times 10^{3}$ copies). Correlation of symptom development in melon test plants and virus titer in source plants was not evaluated closely; however, symptoms developed in most CYSDV-infected melon plants by the time of sampling (4 weeks after inoculation), with most plants developing symptoms approximately 3 weeks after inoculation. In general, symptoms developed more slowly in melon plants with lower virus titers (data not shown).

CYSDV titers in London rocket source plants were considerably lower than in buffalo gourd, ranging from $1 \times 10^{2}$ to $7 \times 10^{2}$ copies (Fig. 2B). However, the infection rate of melon plants inoculated with whiteflies that acquired virus from London rocket source plants was as high as that in melon plants inoculated with whiteflies that acquired the virus from buffalo gourd source plants. Almost all melon plants inoculated with whiteflies that acquired virus from CYSDV-infected London rocket plants became infected (4 melon test plants inoculated per London rocket source plant, for a total of 11 infected/12 inoculated in three experiments). Consistent with the lower virus titer in the London rocket source plants, CYSDV accumulation in melon following transmission from this host was considerably lower than that following transmission from buffalo gourd, ranging from $<10$ to $3 \times 10^{1}$ copies per sample (Fig. 2B).

Virus titers in shepherd's purse source plants ranged from $2 \times 10^{3}$ to $2 \times 10^{4}$ copies (Fig. 2C), which were higher than those for London rocket but well below levels found in the cucurbit hosts. In contrast to London rocket, melon plants inoculated with whiteflies that acquired the virus from shepherd's purse plants had low rates of CYSDV infection. In fact, from the three shepherd's purse plants used as source plants, transmission was detected in only a single inoculated melon plant (4 melon test plants inoculated per shepherd's purse source plant, for a total of 1 infected/12 inoculated in three experiments).

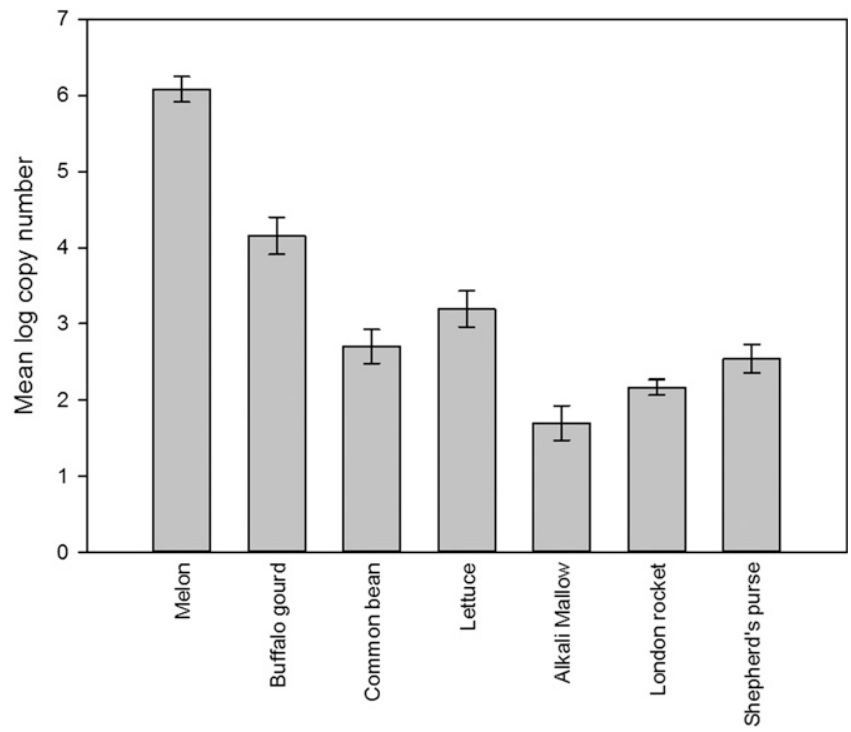

Fig. 1. Accumulation of Cucurbit yellow stunting disorder virus (CYSDV) in seven selected weed and crop hosts. Whiteflies (Bemisia tabaci biotype B; 70 to 100 per host plant) were given a 48-h acquisition access period on CYSDV-infected melon or zucchini source plants followed by a 48-h inoculation access period on seedlings of melon (Cucumis melo) and six weed and crop test plants. Inoculated plants were maintained for 4 weeks in growth chambers and CYSDV titer was determined by reverse-transcription quantitative polymerase chain reaction (efficiency $[E]=91.0 \%$; $R^{2}=1.0$ ). Differences in virus titer among CYSDV-infected plants of each host species were significant $(P=0.05)$.

Table 1. Cucurbit yellow stunting disorder virus transmission rates from zucchini (Cucurbita pepo) to weeds and noncucurbit crop hosts, and from these hosts back to zucchini ${ }^{\mathrm{a}}$

\begin{tabular}{lccc}
\hline Host plant & Symptom expressionb $^{\text {b }}$ & From zucchini to test species) & From test species back to zucchini \\
\hline Zucchini (Cucurbita pepo) & $\mathrm{S}$ & $95 \%(38 / 40)$ & $95 \%(38 / 40)$ \\
Lettuce (Lactuca sativa) & $\mathrm{S}$ & $75 \%(25 / 33)$ & $33 \%(8 / 24)$ \\
Common Bean (Phaseolus vulgaris) & $\mathrm{S}$ & $63 \%(22 / 35)$ & $23 \%(7 / 30)$ \\
Buffalo Gourd (Cucurbita foetidissima) & $\mathrm{S}$ & $84 \%(21 / 25)$ & $100 \%(6 / 6)$ \\
Alkali Mallow (Sida hederacea) & $\mathrm{S}$ & $58 \%(7 / 12)$ & $27 \%(6 / 22)$ \\
Alfalfa (Medicago sativa) & $\mathrm{A}$ & $0 \%(0 / 22)$ & $67 \%(4 / 6)$ \\
London Rocket (Sisymbrium irio) & $\mathrm{A}$ & $100 \%(17 / 17)$ & $89 \%(16 / 18)$ \\
Shepherd's Purse (Capsella bursa-pastoris) & $\mathrm{A}$ & $80 \%(12 / 15)$ & $6 \%(1 / 16)$ \\
\hline
\end{tabular}

${ }^{\text {a }}$ For each transmission, 50 to 70 whiteflies (Bemisia tabaci biotype B) were used, with a 48-h virus acquisition access period followed by a 48-h virus inoculation access period.

b $\mathrm{S}=$ symptomatic and $\mathrm{A}=$ asymptomatic

c Alfalfa was unable to be infected in laboratory transmissions. Infected alfalfa plants were identified from Imperial County, CA fields by reverse-transcription polymerase chain reaction, shipped to the laboratory, and used for transmission experiments. 
CYSDV accumulation in common bean was significantly lower than in the cucurbit hosts (Fig. 1), and the titers in the bean source plants used in these experiments ranged from $<10$ to $2 \times 10^{4}$ copies (Fig. 2D). Furthermore, bean plants infected with CYSDV declined much more rapidly than other source plants. Interestingly, whitefly transmission rates to melon were variable when common bean plants were used as source plants ( 4 to 5 melon test plants inoculated per common bean source plant, for a total of 17 infected/27 inoculated in six experiments). Transmission from some common bean source plants resulted in infection of all inoculated melon plants whereas, for other common bean plants, transmission resulted in only a single infected melon plant. CYSDV accumulation in infected melon plants ranged from $6 \times 10^{1}$ to $3 \times 10^{3}$ copies (Fig. 2D).

\section{Discussion}

The surveys performed in the present study demonstrated that CYSDV has become established in the Imperial Valley. CYSDV outbreaks in the spring crop developed slowly, which likely reflected the low populations of B. tabaci (Chu et al. 2007; Natwick 2009) and low levels of CYSDV infection in reservoir hosts. A similar pattern was reported for $\mathrm{CuLCrV}$, another emergent whitefly-transmitted virus in the Imperial Valley (Hagen et al. 2008). The increasing number of

A

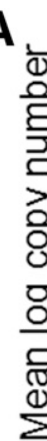

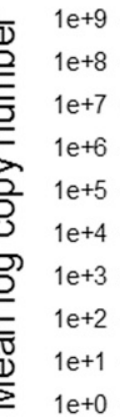
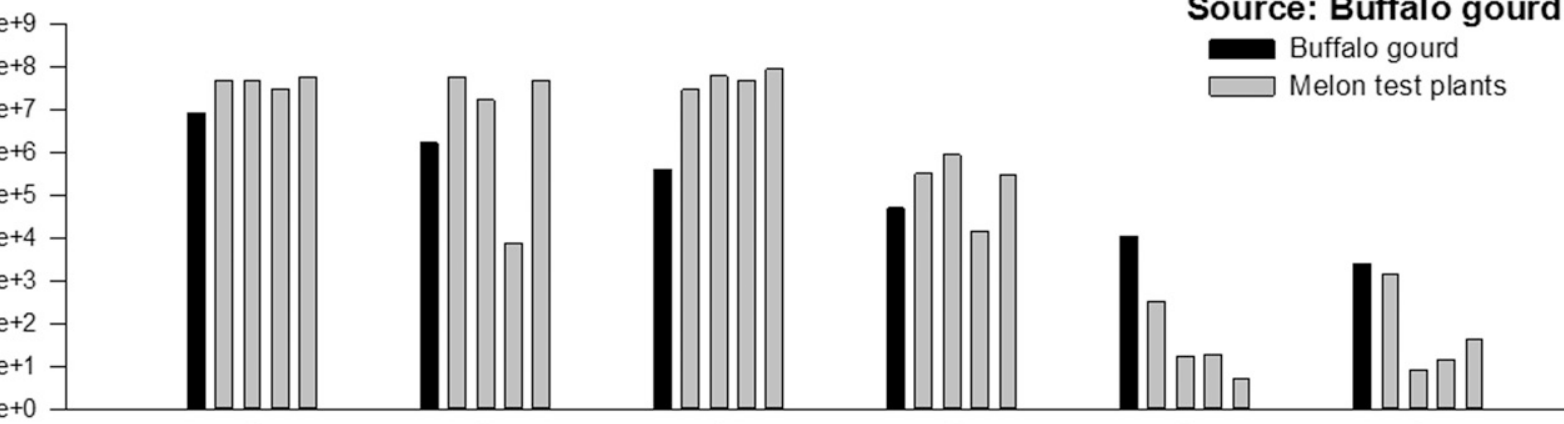

1

2

3

4

5

6

B

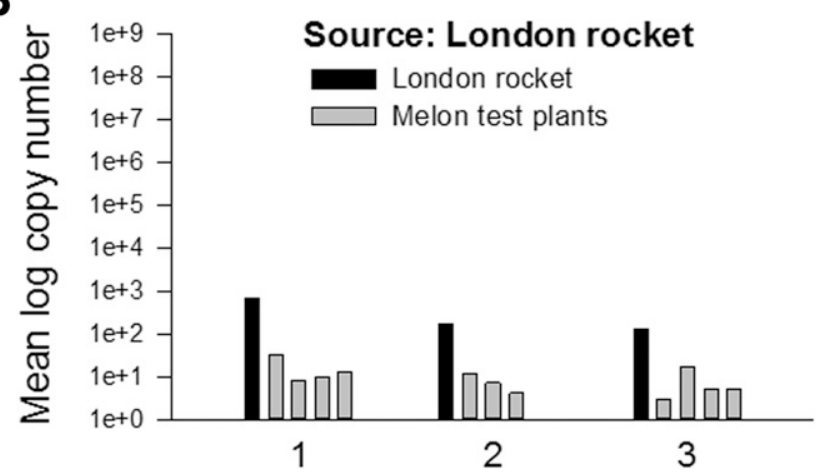

D

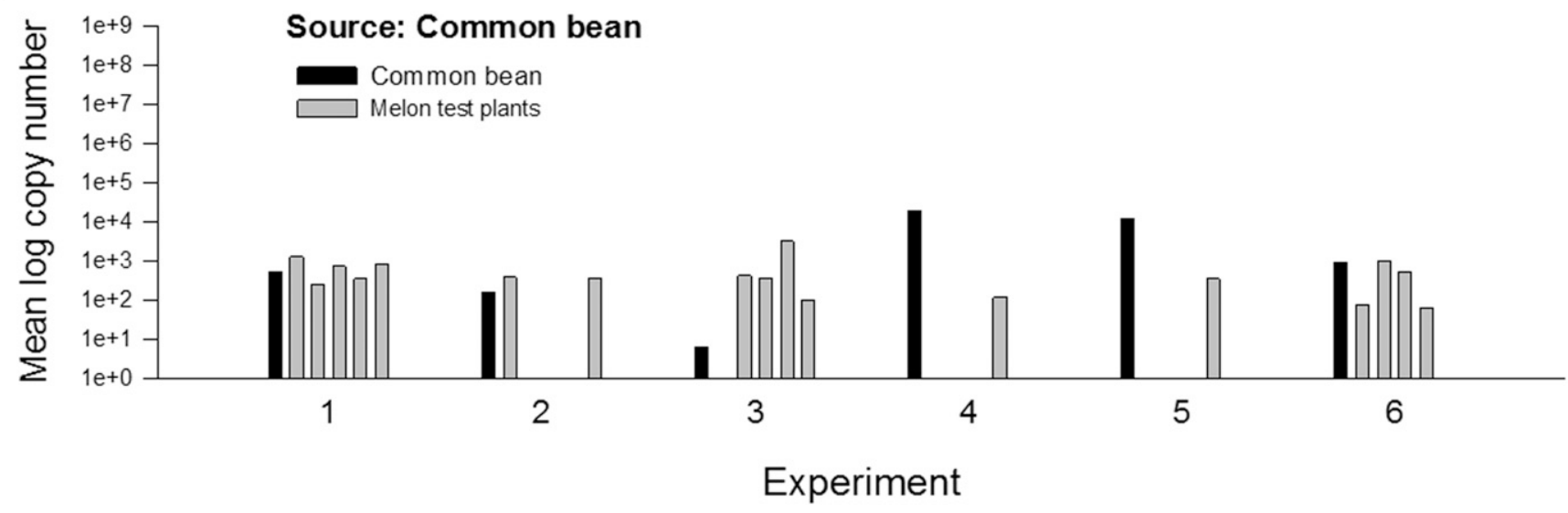

Fig. 2. Comparison of Cucurbit yellow stunting disorder virus (CYSDV) titers in various source plant species with titers in melon test plants following whitefly transmission. Virus titers in CYSDV-infected source plant species were determined by reverse-transcription quantitative polymerase chain reaction (RT-qPCR) within $48 \mathrm{~h}$ of use as virus acquisition hosts. Whiteflies (Bemisia tabaci biotype B) were given a 48-h acquisition access period on CYSDV-infected source plants, collected, and placed into clip cages (35 whiteflies/clip cage) that were attached to the abaxial surface of leaves of melon seedlings (two cages per plant) for a 48-h inoculation access period. Plants were maintained for 4 weeks in growth chambers. Virus titer in leaves of inoculated melon plants was determined by RT-qPCR. A, Buffalo gourd (Cucurbita foetidissima), qPCR efficiency (E) $=96.9 \%, R^{2}=0.999 ;$ B, London rocket (Sisymbrium irio), $\mathrm{E}=98.1 \%, R^{2}=1.0 ; \mathrm{C}$, Shepherd's purse (Capsella bursa-pastoris), $\mathrm{E}=92.0, R^{2}=0.998 ; \mathrm{D}$, Common bean (Phaseolus vulgaris), experiments 1 to 3 : $\mathrm{E}=91.9 \%, R^{2}=1.0$; experiments 4 to 6 (50 whiteflies per clip cage; 100 total used in inoculation), $\mathrm{E}=92.5 \%, R^{2}=0.995$. 
spring melon fields with CYSDV-infected plants as well as the increased incidence of infection within these fields from the first survey in spring 2007 through 2009 indicated increased efficiency of virus overwintering. This may have been due to favorable environmental conditions or an increased number of infected reservoir hosts due to increasing levels of virus inoculum in the Imperial Valley from 2006 to 2008. Indeed, nearly all fall melon plants were infected with CYSDV, which reflected the combination of the presence of CYSDV-infected spring melon crops and high populations of whiteflies present in the Imperial Valley at the time the fall crop was planted.

To better understand the potential for reservoir hosts to serve as CYSDV inoculum sources, it is essential to establish that they can serve as sources of the virus for transmission by the whitefly vector. This study was initiated to further investigate the overwintering capacity of CYSDV in reservoir hosts in the southwestern desert melon-production region, and to evaluate the relationship between virus titer in these hosts and whitefly transmission of CYSDV to cucurbits. Whitefly transmission experiments revealed three categories of potential CYSDV reservoir hosts: very good, moderate, and poor. Melon and buffalo gourd had the highest levels of virus accumulation and were very good sources for whitefly transmission, fully consistent with the high degree of susceptibility of cucurbits to CYSDV. Alkali mallow, a low-growing, perennial weed common around fields, was a poor source, whereas lettuce, common bean, shepherd's purse, and London rocket were moderate sources.

The open-pollinated melon Top Mark, once widely grown in the Imperial Valley, accumulated significantly higher levels of CYSDV than two contemporary $\mathrm{F}_{1}$ hybrid cultivars, although their plant condition and symptom severity ratings were similar. This suggests that factors other than virus accumulation may affect symptom development in cucurbits. With the exception of melon, the highest level of CYSDV was detected in the cucurbit weed buffalo gourd. Indeed, the lowest levels of virus accumulation in buffalo gourd source plants were comparable with the highest levels in the noncucurbit hosts (Figs. 1 and 2A). The finding that $100 \%$ of melon test plants were infected with CYSDV and with high titers following whitefly transmission from buffalo gourd source plants indicated that this perennial weed is an important potential reservoir host. Furthermore, the positive correlation between virus titer in buffalo gourd source plants and efficient transmission to melon plants was in agreement with results of studies on other members of the genus Crinivirus ( $\mathrm{Ng}$ et al. 2004; Wintermantel 2010; Wintermantel et al. 2008). Buffalo gourd is a perennial cucurbit weed found around agricultural production in desert regions of the southwestern United States. It has a deep taproot and can survive extended periods of below-freezing temperatures. Therefore, it is well suited to serve as an overwintering reservoir of CYSDV. Following whitefly acquisition of CYSDV from buffalo gourd plants in the spring and transmission to nearby melon plants, the virus can rapidly build up and spread to and within melon fields and nearby weed hosts via increasing populations of whiteflies.

Alkali mallow was previously identified as a naturally infected weed host of CYSDV but the infection rate of sampled plants from the field was relatively low (8.3\%; Wintermantel et al. 2009). In the present study, the infection rate of greenhouse-grown alkali mallow plants that had been exposed to viruliferous whiteflies was relatively high (58\%; Table 1). Here, it should be noted that greenhousegrown alkali mallow plants differ from field-grown plants in two respects: (i) a lack of elongated trichomes on leaves and (ii) a more upright growth habit. It is possible that high densities or other properties of trichomes on field-grown alkali mallow plants may deter or interfere with whitefly feeding and, therefore, transmission of CYSDV. Due to the differences between field- and greenhousegrown alkali mallow plants, this host was not included in the virus transmission study. However, these results suggest that the physical characteristics of alkali mallow may make it less important as a reservoir host in the field and reveal the complexity of factors influencing virus transmission and epidemiology.

Some of the symptomatic CYSDV hosts were efficient sources for acquisition and transmission of CYSDV by whiteflies to melon and zucchini, whereas others accumulated virus relatively well but were poor sources for virus transmission. London rocket plants were readily infected by CYSDV in whitefly transmission experiments (Table 1) but did not develop symptoms. Furthermore, the finding that CYSDV-infected London rocket plants served as an effective source of CYSDV for whitefly transmission indicates that symptomless hosts can be efficient sources of the virus for whitefly transmission to cucurbits. In contrast, shepherd's purse, another member of the Brassicaceae family, was a poor source of CYSDV for whitefly transmission to cucurbits (Table 1), even though the virus accumulated to levels comparable with those in London rocket (Figs. 1 and $2 \mathrm{~B}$ and $\mathrm{C}$ ). Moreover, the poor transmission of CYSDV from shepherd's purse by whiteflies cannot be attributed to vector preference because (i) it is a good host for B. tabaci biotype B (W. M. Wintermantel, unpublished) and (ii) in transmission experiments, there were no obvious differences in whitefly feeding behavior on shepherd's purse compared with more efficient source plant species such as London rocket, buffalo gourd, or cultivated cucurbits.

Common bean had moderate levels of CYSDV accumulation and was moderately efficient as a source for whitefly transmission and subsequent virus accumulation in inoculated melon plants. Interestingly, there was an inverse correlation between virus titer in common bean plants and whitefly transmission, because source plants with lower virus titers had higher transmission rates (Fig. 2D). In addition, virus titer in the common bean source plants did not affect subsequent virus accumulation in inoculated melon test plants. We noted a possible association of whitefly feeding preference with efficiency of transmission in common bean. Bean plants infected with CYSDV declined very rapidly, with leaves desiccating quickly. Such plants are poor hosts for $B$. tabaci, indicating that poor leaf quality may negatively influence feeding by whiteflies and explain the negative correlation between virus titer and whitefly transmission from common bean plants. Thus, plants with lower virus levels and more succulent leaves may be better sources for virus acquisition than plants with higher virus titers and poor-quality leaves that are less desirable for whitefly feeding.

Lettuce is a potential CYSDV bridge crop, with production overlapping the fall and spring melon seasons. Lettuce planting begins near the middle of the fall melon season and harvesting continues through March, at which time early-planted spring melon crops have started flowering. CYSDV accumulates relatively well in lettuce (Fig. 1), and induces mild leaf symptoms. However, the finding that whitefly transmission from CYSDV-infected lettuce to zucchini occurred at low rates indicates that lettuce is a poor transmission host. This is also consistent with the failure to detect CYSDV in surveys of spring lettuce fields (E. T. Natwick, R. L. Gilbertson, and W. M. Wintermantel, unpublished). Therefore, lettuce does not appear to be an important CYSDV inoculum source for spring melon crops in the Imperial Valley.

For cucurbit hosts, there was a positive correlation between viral titer and whitefly transmission but, in potential reservoir hosts, variable rates of whitefly transmission from different source species with similar CYSDV titers revealed complexity in determining the potential of a given host to serve as a virus reservoir. The present study focused on the relationship between virus accumulation in potential reservoir hosts and whitefly transmission to cucurbit hosts. Thus, although virus titer in the source plant influenced the ability of whiteflies to acquire and transmit CYSDV, other factors also contributed to transmission efficiency. These included physical traits such as growth habit and leaf structural features, as revealed by differences between field- and greenhouse-grown alkali mallow; and whitefly feeding preference for virus-infected plants as exemplified by common bean. On the other hand, it is not clear why shepherd's purse, which accumulated moderately high levels of CYSDV, was a poor source for CYSDV transmission. Together, these results demonstrate the challenge of identifying epidemiologically important reservoir host plants as well as factors that influence virus transmission.

Perennials such as buffalo gourd, which is a very good source for whitefly transmission of CYSDV and occurs at the interface between desert areas and farmland, and possibly alfalfa, an abundant crop in 
the Imperial Valley, may serve as long-term reservoirs and as inoculum sources for transmission of the virus into melon plants and other hosts each year. Variation in disease severity from year to year will be influenced by the relative abundance of CYSDV reservoir host plants that are efficient sources for acquisition and transmission of the virus, proximity of such host plants to susceptible crops, and abundance of the whitefly vector. Increased knowledge of the biological and physical issues that determine the importance of different source plant species as CYSDV reservoirs should aid development of improved management practices for this economically important emergent virus.

\section{Acknowledgments}

We thank A. Cortez and L. Hladky, USDA-ARS in Salinas, for conducting whitefly transmission experiments and RT-qPCR analysis of samples, respectively; R. Nelson and J. Dessert of the Imperial County, CA Agricultural Commissioner's Office for identifying the location of melon fields and for assistance in field surveys; and M. Lopez, E. Sambrano, and R. Lara of the University of California Desert Research and Extension Center in Holtville for assistance with field surveys. This work was supported, in part, by the California Melon Research Board, the Western IPM Center IPM Issues Grant Program (07-001492-UA4), and the Western Regional IPM program (2008-03024/GRANT00383452).

\section{Literature Cited}

Abou-Jawdah, Y., Sobh, H., Fayad, A., Lecoq, H., Delecolle, B., and Trad-Ferre, J. 2000. Cucurbit yellow stunting disorder virus - A new threat to cucurbits in Lebanon. J. Plant Pathol. 82:55-60.

Berdiales, B., Bernal, J. J., Sáez, E., Woudt, B., Beitia, F., and Rodríguez-Cerezo, E. 1999. Occurrence of Cucurbit yellow stunting disorder virus (CYSDV) and beet pseudo-yellows virus in cucurbit crops in Spain and transmission of CYSDV by two biotypes of Bemisia tabaci. Eur. J. Plant Pathol. 105:211-215.

Brown, J. K., Guerrero, J. C., Matheron, M., Olson, M., and Idris, A. M. 2007. Widespread outbreak of Cucurbit yellow stunting disorder virus in melon, squash, and watermelon crops in the Sonoran Desert of Arizona and Sonora, Mexico. Plant Dis. 91:773.

Bustin, S. A., Benes, V., Garson, J. A., Hellemans, J., Huggett, J., Kubista, M., Mueller, R., Nolan, T., Pfaffl, M. W., Shipley, G. L., Vandesompele, J., and Wittwer, C. T. 2009. The MIQE guidelines: Minimum information for publication of quantitative real-time PCR experiments. Clin. Chem. 55:611-622.

Célix, A., López-Sesé, A., Almarza, N., Gómez-Guillamón, M. L., and RodriguezCerezo, E. 1996. Characterization of Cucurbit yellow stunting disorder virus, a Bemisia tabaci-transmitted closterovirus. Phytopathology 86:1370-1376.

Chu, C. C., Barnes, E., Natwick, E. T., Chen, Y., Ritter, D., and Henneberry, T. J. 2007. Trap catches of the sweetpotato whitefly (Homoptera: Aleyrodidae) in the Imperial Valley, California, from 1996 to 2002. Insect Sci. 14:165-170.

Cotillon, A. C., Desbiez, C., Bouyer, S., Wipf-Scheibel, C., Gros, C., Delecolle, B., and Lecoq, H. 2005. Production of a polyclonal antiserum against the coat protein of Cucurbit yellow stunting disorder crinivirus expressed in Escherichia coli. Bull. OEPP/EPPO Bull. 35:99-103.

Dellaporta, S., Wood, J., and Hicks, J. B. 1983. A plant DNA minipreparation: Version II. Plant Mol. Biol. Rep. 1:19-21.

Desbiez, C., Lecoq, H., Aboulama, S., and Peterschmitt, M. 2000. First report of Cucurbit yellow stunting disorder virus in Morocco. Plant Dis. 84:596.

Dickey, A. M., Osborne, L. S., Shatters, R. G., Jr., Hall, P. M., and McKenzie, C. L. 2013. Population genetics of invasive Bemisia tabaci (Hemiptera: Aleyrodidae) cryptic species in the United States based on microsatellite markers. J. Econ. Entomol. 106:1355-1364.

Hagen, C., Rojas, M. R., Sudarshana, M. R., Xoconostle-Cazares, B., Natwick, E. T., Turini, T. A., and Gilbertson, R. L. 2008. Biology and molecular characterization of Cucurbit leaf crumple virus, an emergent cucurbit-infecting begomovirus in the Imperial Valley of California. Plant Dis. 92:781-793.

Hassan, A. A., and Duffus, J. E. 1991. A review of a yellowing and stunting disorder of cucurbits in the United Arab Emirates. Emir. J. Agric. Sci. 2:1-16.

Kao, J., Jia, L., Tian, T., Rubio, L., and Falk, B. W. 2000. First report of Cucurbit yellow stunting disorder virus (genus Crinivirus) in North America. Plant Dis. 84:101.

Kuo, Y.-W., Rojas, M. R., Gilbertson, R. L., and Wintermantel, W. M. 2007. First report of Cucurbit yellow stunting disorder virus in California and Arizona, in association with Cucurbit leaf crumple virus and Squash leaf curl virus. Plant Dis. 91:330.

López-Sesé, A. I., and Gómez-Guillamón, M. L. 2000. Resistance to Cucurbit yellow stunting disorder virus (CYSDV) in Cucumis melo L. HortScience 35: 110-113.

Louro, D., Vaira, A. M., Accotto, G. P., and Nolasco, G. 2000. Cucurbit yellow stunting disorder virus (genus Crinivirus) associated with the yellowing disease of cucurbit crops in Portugal. Plant Dis. 84:1156.

McCreight, J. D., and Wintermantel, W. M. 2012. Genetic resistance in melon PI 313970 to Cucurbit yellow stunting disorder virus. HortScience 46:1-6.

McKenzie, C. L., Bethke, J. A., Byrne, F. J., Chamberlin, J. R., Dennehy, T. J., Dickey, A. M., Gilrein, D., Hall, P. M., Ludwig, S., Oetting, R. D., Osborne, L. S., Schmale, L., and Shatters, R. G., Jr. 2012. Distribution of Bemisia tabaci (Hemiptera: Aleyrodidae) biotypes in North America after the Q invasion. J. Econ. Entomol. 105:753-766.

McKenzie, C. L., Hodges, G., Osborne, L. S., Byrne, F. J., and Shatters, R. G., Jr. 2009. Distribution of Bemisia tabaci (Hemiptera: Aleyrodidae) biotypes in Florida-investigating the Q Invasion. J. Econ. Entomol. 102:670-676.

Natwick, E. T. 2009. Insecticide seed treatments for whitefly control on cantaloupe melon, 2007. Online publication. Arthropod Manage. Tests 34. doi: 10.4182/amt.2009.E40

Ng, J. C. K., Tian, T., and Falk, B. W. 2004. Quantitative parameters determining whitefly (Bemisia tabaci) transmission of Lettuce infectious yellows virus and an engineered defective RNA. J. Gen. Virol. 85:2697-2707.

Papayiannis, L. C., Hunter, S. C., Iacovides, T., and Brown, J. K. 2010. Detection of Cucurbit yellow stunting disorder virus in cucurbit leaves using sap extracts and real-time TaqMan reverse transcription (RT) polymerase chain reaction (PCR). J. Phytopathol. 158:487-495.

Polston, J. E., Hladky, L. L., Akad, F., and Wintermantel, W. M. 2008. First report of Cucurbit yellow stunting disorder virus in cucurbits in Florida. Plant Dis. 92: 1251.

Tzanetakis, I. E., Martin, R. R., and Wintermantel, W. M. 2013. Epidemiology of criniviruses: An emerging problem in world agriculture. Front. Microbiol. 4:119.

Wintermantel, W. M. 2010. Transmission efficiency and epidemiology of criniviruses. Pages 319-331 in: Bemisia: Bionomics and Management of a Global Pest. P. Stansly and S. E. Naranjo, eds. Springer, New York.

Wintermantel, W. M. Semi-persistent whitefly-transmitted viruses: Crinivirus. In: Vector-Mediated Transmission of Plant Pathogens. J. K. Brown, ed. American Phytopathological Society, St. Paul, MN (in press).

Wintermantel, W. M., Cortez, A. A., Anchieta, A. G., Gulati-Sakhuja, A., and Hladky, L. L. 2008. Co-infection by two criniviruses alters accumulation of each virus in a host-specific manner and influences efficiency of virus transmission. Phytopathology 98:1340-1345.

Wintermantel, W. M., Hladky, L. L., Cortez, A. A., and Natwick, E. T. 2009. A new expanded host range of Cucurbit yellow stunting disorder virus includes three agricultural crops. Plant Dis. 93:685-690.

Wisler, G. C., and Duffus, J. E. 2001. Transmission properties of whitefly-borne criniviruses and their impact on virus epidemiology. Pages 293-308 in: Virus-Insect-Plant Interactions. K. F. Harris, O. P. Smith, and J. E. Duffus, eds. Academic Press, San Diego, CA.

Wisler, G. C., Duffus, J. E., Liu, H.-Y., and Li, R.-H. 1998. Ecology and epidemiology of whitefly-transmitted closteroviruses. Plant Dis. 82:270-280. 